\title{
Milligram per Second
}

National Cancer Institute

\section{Source}

National Cancer Institute. Milligram per Second. NCI Thesaurus. Code C85712.

Milligrams per second. 